\title{
Who needs a father? South African men reflect on being fathered
}

\author{
Lindsay Clowes, Kopano Ratele and Tamara Shefer
}

\begin{abstract}
The legacy of apartheid and continued social and economic change have meant that many South African men and women have grown up in families from which biological fathers are missing. In both popular and professional knowledge and practice this has been posed as inherently a problem particularly for boys who are assumed to lack a positive male role model. In drawing on qualitative interviews with a group of South African men in which they speak about their understandings of being fathered as boys, this paper makes two key arguments. The first is that contemporary South African discourses tend to pathologize the absence of the biological father while simultaneously undermining the role of social fathers. Yet, this study shows that in the absence of biological fathers other men such as maternal or paternal uncles, grandfathers, neighbours, and teachers often serve as social fathers. Most of the men who participated in this study are able to identify men who - as social rather than biological fathers - played significant roles in their lives. Secondly, we suggest that while dominant discourses around social fatherhood foreground authoritarian and controlling behaviours, there are moments when alternative more nurturing and consultative versions of being a father and/or being fathered are evident in the experiences of this group of men.
\end{abstract}

\section{Introduction}

Popular and professional discourses suggest that the absent father is the source of many societal ills, and that biological fathers are critical for the mental and psychological health of boys growing into young men. Psychology has long problematized the figure of the absent father, and sons who grow up in the absence of a biological father are generally understood to have been deprived (for a discussion of these discourses see Lupton and Barclay 1997, Lewis and Lamb 2004, Richter and Morrell 2006). In this paper, we suggest that such understandings emerge out of particular conceptualizations of 'the family', out of the privileging of the nuclear family model comprising biological mother, father, and children. It is specifically the absence of the biological father in the patriarchal nuclear family that is presented as problematic, and problematic specifically for the boy child. Such conceptualizations and normative assumptions of family privilege the biological over the social, ahistorically essentializing and normalizing particular family structures and particular gender regimes. And yet there is a great deal of evidence to suggest that far from the basic building-block of human communities across time and space, the stereotypical patriarchal nuclear family as understood in much contemporary legislation and social policy is a relatively recent invention (Burgess and Russell 2004). Its roots lie in centuries of social, political, and economic change, expressed/exemplified in a global 
heteronormative and patriarchal capitalist system (Brown and Barker 2004). There is, it would seem, nothing natural about the nuclear family, and, far from being the essential building-block of a stable society, the rising numbers of single parent households suggest it is also a fragile and unstable arrangement. Such a model has, moreover, never been the dominant framework either in South Africa or other parts of the continent (see for example Crehan 1997, Oyewumi 1997, Geffray 1990 cited in Arnfred 2001, Bozalek 2004, 2007). As Brown and Barker note, 'The roles of uncles, grandfathers, stepfathers and the extended kin network of the majority world has not been examined nearly as much as the nuclear family of the minority world' (2004, p. 29).

Recognition that fatherhood is a position arising out of social forces rather than simply a reproductive role is emerging in South African writing (see, for example, Richter and Morrell 2006, Mkhize 2006, Langa 2010). Somehow though, it seems to need constant iteration. Fatherhood as a key signifier of successful masculinity (Morrell and Richter 2006, Morrell 2007, Mfecane 2008) therefore has more to do with the social construction of masculinity than with the implantation of sperm in an ovum. Given the stereotypic socioeconomic obligations of heading households and breadwinning associated with fatherhood, it is important to acknowledge that for the majority of South African men achieving successful masculinity through social fatherhood is challenging (Wilson 2006). A decade ago census data showed that 'only $7 \%$ of all men named as bringing in the most money are not household heads, while this is the case for $21 \%$ of female main moneyearners' (Statistics South Africa 2000, p. 6). In other words, even though some women are clearly the main breadwinners, men remain more likely to be perceived as heading the household. Contemporary South Africa continues to experience high levels of unemployment, with the unemployment rate at the beginning of 2011 at $25 \%$ (Statistics South Africa 2011), and the recent global economic crisis makes it particularly challenging for poor men to live up to the expectations of hegemonic fatherhood and the breadwinner/protector role this implies (see, for example, Wilson 2006, Mfecane 2008).

Such constructions of masculinity are nowhere more powerfully represented than in the role of the disciplinarian father, presiding as sovereign over the household. Fathers and fatherhood have thus emerged as key concerns in critical men's studies/masculinities studies in South Africa over the last decade (for example, Richter and Morrell 2006, Swartz and Bhana 2010). Countering the pathologizing gaze of mainstream psychology on gender, fathers, and absent fathering (see critiques by Busfield 1996, Lupton and Barclay 1997), masculinities studies research has employed a feminist lens to explore the challenges men (and women) face in the light of dominant ideologies on masculinity in changing contexts. Such research has foregrounded historical and contemporary material contexts, including the migrant labour system, poverty, and HIV/AIDS, which undermine many men's capacity either to be present or to live up to normative expectations (for example, Morrell and Richter 2006, Wilson 2006, Shefer et al. 2007, Mfecane 2008). Other studies show how dominant discourses of masculinity produce, authorize, and legitimize violent practices bymen towards othermen,women, and children (see, for example, Gibson andRosenkrantz Lindegaard 2007, Hearn 2007, Ratele 2008, Clowes et al. 2010).We hope to contribute to this body of work by exploring a group ofmen's subjective accounts of being fathered in SouthAfrica.Our analysis here is underpinned by two concerns that we argue will contribute to a more complex understanding of practices 
of fathering and experiences of being fathered. Firstly, we suggest that while much of the international and South African research literature (Flouri and Buchanan 2003, BronteTinkew et al. 2006, Choi and Jackson 2011, Holborn and Eddy 2011) is focused on biological fathers and their absence, our study foregrounds the value of social fathering that has been problematically marginalized in the literature. Secondly, while acknowledging that problematic discourses on fatherhood (defining masculinity through independent, authoritarian, controlling heads of households who provide, protect, and are violent) remain dominant in the narratives we have collected here, we also want to foreground the existence of narratives that destabilize these discourses: narratives that demonstrate alternative experiences and practices of fathering and being fathered.

\section{The study}

The data analysed here emerge from a qualitative study conducted as part of an undergraduate research module with gender studies students at the University of the Western Cape and in collaboration with the Crime, Violence and Injury (CVI) programme of the Medical Research Council (MRC) and the University of South Africa (UNISA). Students who register for this research module are active participants as researchers, engaging in a 'real' research project and producing data that may go further than the classroom. The collaboration with theMRC/UNISA CVI programme began with a focus on masculinity and violence before moving on to explore fatherhood and male role models, as exemplified in the research question: 'How do men who grew up in the apartheid era understand their experiences of being fathered and cared for as boy children and adolescents?'

The methodology of the study was developed collaboratively in the classroom, and students were trained in ethics of research and interviewing skills before conducting the interviews. After drawing up the appropriate informed consent that guaranteed voluntary participation, confidentiality, and anonymity, as well as the right to withdraw at any time, each student interviewed three men aged 35 or older about their memories of their experiences of being fathered 25 or more years ago. As in previous years, the research project on fatherhood, conducted in 2009, was structured in such a way that the 88 students who completed the course worked independently until they had completed their three interviews and begun a qualitative thematic analysis of their data. Out of a total of 264 interviews, we selected a convenient subsample (29 of those available) for analysis.1 Of these, all but one had children, and all were aged between 35 and 68. Two of the men would have been classified as 'white' under the apartheid regime, 9 'coloured', and 18 'black'.2 While acknowledging that family structures are fluid and shifting rather than static and fixed, 12 of the men reported that they grew up in what can loosely be called 'nuclear' households, although at least one of these indicated that his father was a migrant worker and thus away from home much of the year, and another had a father imprisoned on Robben Island for a large part of his childhood. All of these men were able to identify at least one man, and several participants were able to identify many men (uncles, grandfathers, and school teachers) who had taken on fathering roles in their lives. While all lived in Cape Town at the time of the interview, most had grown up far from Cape Town. Two had grown up in Johannesburg, one in Port Elizabeth, and another in Umtata. Eleven had grown up in rural parts of the Eastern Cape, six more in rural parts of the Western Cape, seven were raised in Cape Town, and another spent his childhood moving 
between Cape Town and Port Elizabeth. A qualitative thematic analysis informed by critical discourse analysis (drawing on the work of, for example, Potter and Wetherell 1987, Parker 1992, Burman and Parker 1993, van Dijk 1993) was conducted on the transcripts. Our analysis applied a gendered discourse analytic lens in order to unpack the meanings that participants make of their experiences, with a particular focus on the way in which the language used served a particular function within the large framework of normative discourses on gender, masculinities, and fathering. In the presentation of direct quotes from participants, pseudonyms are used to ensure anonymity.

\section{Discussion of findings}

Four main overlapping themes emerged out of the data. The first was the way in which so many of the men interviewed spoke of, or alluded to, the tensions between the presence and significance of biological versus social fathers in their own childhood. Linked to this was the tension between the provider and protector role of fathers, and the emotional and nurturing needs provided on a day-to-day basis by father figures such as uncles, grandfathers, or neighbours. Thirdly, our data suggest that fathers' attempts to perform normative masculine roles as the autonomous decision-maker and head of the household served to marginalize them from both family and community support networks, with the resulting anxieties and insecurities often expressed through violence or the threat of violence. Finally we present moments in the data where fathers or father figures are represented in more positive, non-hegemonic ways. Father figures versus biological fathers

Those who identified their biological fathers as significant in their own childhoods did so by foregrounding the physical and emotional presence of their fathers in their daily lives:

My father meant a lot to me in the sense he was always there for me. (Siyabonga)

My father, I could say he was always there for me, always stood up for me, taught me a lot of things, spent quality time with me . . . and you name it, I mean just taught me a lot of things which I still treasure today and which I'm trying to pass on to my son. (John)

At the same time, however, for those whose biological fathers were absent for all or parts of their childhood there seemed to be no shortage of adult men available to fill the gap. Grandfathers, uncles, and neighbours, even a school principal, were identified as father figures and role models:

It was my father and my grandfather because . . . I grew up under their presence. When I was a boy always with my grandfather but when I was a teenager I was with father. My grandfather usually wakes me up in the morning and goes to the garden to make some planting. This is where I have learned to work hard as a man. It is important to me because I'm able to work for my wife and my children. (Sipho)

... the nicest thing about being fathered as a boy is that you are free in that everybody takes care of you . . . When I grew up I did not have a father, I was raised by my grandparents, my mother's parents. My uncle was my role model, because he went to work in Gauteng at the mine there and so he provided for me and the rest of the family. 
He took care of me in a way that my father never did even though he was also working. (Xolile)

... all in all it was mostly my grandfather and my uncle who assisted me in my formation to become an adult. (Dave)

For another man it was the headmaster of the orphanage in which he was placed:

... he was like a father tome, very humble man but also strict . . . he tried his best to see to all of us because there were nearly 200 boys in the orphanage, he was father figure to all of us ... (Jacob)

For these men (reinforcing the findings of Swartz and Bhana 2010), what emerges as important in their narratives is the physical presence of an involved and engaged adult male. And yet, despite highlighting and clearly valuing the presence of these men - and often more than one - in their lives, they simultaneously insisted on the significance of the absence of their biological fathers:

There was no real bond between me and my biological father when I grew up as a boy ... as a teenager ... you have no idea life was very difficult because I had to in a way take care of myself figuring out how to tackle life's issues ... I mean growing up without a father is not an easy thing more especially we as men because there are things that sometimes you would like to share with your father but you can't because he is not always around . . . (Dave)

. . my father migrated to Cape Town when I was still very young in search for employment, he never played a huge role in my upbringing. My uncle (my father's brother) and the father from the neighbourhood [older man/father figure living in the community] were always there for me. However, my father was always supporting me financially and the whole family, but financial support was not enough for me as I needed to bond with him and his love the most. These two father figures played a very vital role in my childhood and when I was an adolescent. You should know that it is very difficult to grow up without your father, especially as a boy . . . The fact that I was brought up with other father figures, not my biological father was a negative aspect for me because it is very difficult to relate to someone who is not your biological father. (Bulumko)

Both these men foregrounded the existence of social fathers in their lives, underlining the importance of extended families and the nurturing practices of men other than their biological fathers. Dave identified his grandfather and his uncle, Bulumko his uncle and his neighbour. Yet despite this, both expressed the view that they had lacked something; that only their biological fathers could help them navigate their way through the challenges of growing up. While not for a moment dismissing the ways in which either makes sense of his own history, we suggest here that a more critical analysis is necessary on the part of the academy. Biological fatherhood is, after all, unknowable other than through the social. The powerful reproductive essentialism that foregrounds a biological connection over the social (over the complex relationships built up through the familiarity of day-to-day interactions between and amongst uncles and grandfathers as well as male 
neighbours, teachers, and older siblings) should be challenged. Given the unequivocal presence of a range of nurturant men in the boyhoods of our participants, it seems it may be the social imperative of the (mythologized and idealized) biological father, produced through popular discourse and rubber-stamped by professional discourse that creates the narrative of deficit. The providing protector In explaining what made a good father in their eyes, the men involved in this study foregrounded providing and protecting. Reflecting the findings of a number of local studies (Niehaus 2005, Sideris 2005, Hosking 2006, Hunter 2006, Swartz and Bhana 2010) a key element defining a good father was his ability to provide financially and to undertake the labour involved in protecting family members from economic hardships. Abdul felt acknowledged and affirmed by his own father precisely because he had achieved a measure of economic success:

Like you have your own home, you got a car, you got you got er your house is paid up, and um you earn a nice living, and er your children is educated and er stuff like that and even the way like my children that is married they all got their own houses and my father, their grandfather is very proud. (Abdul)

... I have learned that a man has to be provider for your family, to set achievable goals, and be a good example even to your siblings, and also to be a respected person in your community. (Simphiwe)

While reinforcing the centrality of breadwinning in signalling successful masculinity, participants simultaneously interwove breadwinning with protecting the family. Used almost interchangeably in the discourse of participants, the roles of protector and provider are conflated, both implying the power relations inherent in the position of the patriarch:

I still respect him because he always provided for the family and protected us. He also taught me discipline and hard work. (Xola)

My father always told me that in this world ... a good man always protects and provides for his family. (Themba)

One thing about my dad is that he loves his children and even though he did not say it but through his actions and protective ways that love came out, he protected what he treasured. (Sandile)

... because when he passed on, this thing was so printed into my mind, that I have to do the right thing. If you leave school you have to work. You not forced to leave school to go work but once you start working you don't just quit and lie around, cause that's not a man's job, it's not the thing for a man to do, he must provide, he must work every day ... To be a man ... you've gotta provide, you've gotta protect your family. (John)

Men able to fulfil the economic demands inherent in the role of breadwinner earned the respect of their sons as noted by Siswe: 'I still respect my father for the way he disciplined us and provided us with the necessities of this life'. In contrast Xolile remembered that he 'always felt humiliated by him [his biological father] because he was not taking care of me 
and I could not have all the things that other children had'. Further underlining the importance of men's obligation to provide financially is Clint's shock on finding out that the father he had idolized as a child had not fulfilled these financial obligations:

I was under the impression that he was the provider ja, the sole provider, the reason being because of me hero worshipping him, it blinded me in not seeing anything wrong with my dad and it was only at a later stage that I found out what type of person he really was. It was only at the age of 43 that I really came to know what my father really was and I was quite disappointed and I also felt devastated, when I found out that he wasn't really a provider and kept his money for himself and as an alcoholic . . . not having money for his family, because he didn't give money for his family and my mother and it was really my mother who really raised us. (Clint)

Clint's sense of disillusion revolves around his father's failure to fulfil hegemonic fatherhood. In this narrative, his father was, quite literally, not the man Clint imagined him to be. At the same time, as Clint notes almost in passing, it was his mother who 'really' raised him and his siblings. Admiration and an appreciation of mothers as positive role models by their sons have been noted in other local South African studies, especially in households where biological fathers are missing (Langa 2010). However, while Clint positioned his father as choosing to evade the provider/protector role, the current economic climate and high unemployment rates deny the possibility of successfully fulfilling the breadwinner role to many contemporary men (Silberschmidt 2004, Walker 2005, Hunter 2006). Added to this the large numbers of (primarily female) single-parent households suggests that, while it might not be labelled as 'breadwinning', women have frequently taken on the economic burdens of raising children and maintaining the household:

You know . . . during those times it was really difficult, because amaBhulu (Afrikaners) were treating us very badly because our fathers would stay for a year working in the mines so that they can buy cows to work in the garden. We would sleep without food during those times. My mother would look after our daily needs as children while my father was away as a migrant worker . . . we were going to school without wearing shoes or having proper uniform at times. Nevertheless we survived. (Siso)

... my father was working in Johannesburg in the mines as all the fathers of that Province were working at. Although the situation at home was terrible, we had no food sometimes; my mother had to look after us alone. (Siswe)

As Siswe, Siso, and Clint noted, where fathers failed to live up to gendered expectations and aspirations around breadwinning, providing, and protecting, mothers stepped in. Despite this, breadwinning and protecting remain central to the construction of successful masculinity in the eyes of our participants (see also Morrell and Richter 2006, Swartz and Bhana 2010). Again, there is nothing natural about this. In contrast there is substantial evidence to suggest that breadwinning and protecting were far less central to successful masculinity in the past. In Europe, Lupton and Barclay (1997, p. 38) suggest that the ideal of the male breadwinner and dependent housewife is a relatively recent invention. In Africa and elsewhere, as a number of scholars have noted (McClintock 1995, Burke 1996, 
Sinha 1997, Barnes 1999, Moane 1999, Markowitz 2001, Lindsay 2007), these roles are both more recent and less stable than assumed. Shaped and permeated by the projects of imperialism, colonialism, and racist industrialization, the local roles of breadwinner/protector and subordinate/dependent housewife emerged out of interactions with local practices that wove together to reproduce the logic of patriarchal power.

\section{Fathers as patriarchs}

Embedded in the construction of men as household heads and leaders across domestic and public terrains are notions of strength, independence and self-sufficiency, dominance and control. Indeed implicit in the very meaning of the term patriarch (conflated as it is with fatherhood) is the notion of masculinity as powerful, as in control of and apart from subordinate men, women, and children. Certainly almost all of the men involved in this study reported that their adult male role models had taught them that doing adult masculinity involved being independent, 'standing on one's own two feet', and the denial of interdependence or vulnerability (see also Clowes 2005):

My father's own experience taught me to be man enough and now I don't regret that because if he was still alive he would proud of me. I'm the man who is able to do everything by myself. (Thabo)

Like I said, he taught us to be independent, responsible and to look after ourselves because he knew we were going to get older and were going to have to make our own choices. (Ahmed)

.. . uhm, the fact that he was strong, he would prove it verbally and physically and in our community it was a matter of you must stand up for yourself cause no one else is going to do it for you. (Clint)

In the narratives of our participants, threats to this masculine autonomy and control over others were countered through aggression and violence. As Ratele (2008) and Seedat et al. (2009) have noted, male violence towards women and other men is a major problem and a key priority in SouthAfrica. According to our participants, a social father's violence was legitimate when it was perceived as serving to 'defend' or 'protect' the family. Khulubuse's uncle

... had to protect his family but my uncle hated people who disrespected him and that's when he would fight and hit them. (Khulubuse)

Uhm, ja, defending the family in the sense or even disciplining. Defending the family in the sense that if someone said something about one of the sisters . . my dad went over and he sorted him out there and then physically ... there was no two ways, it was either physically or swearing or whatever. (Clint)

In both explaining and inadvertently rationalizing male violence, this discourse positions certain individuals as needing protection, as dependents, and in order to be protected these dependents must do as they are told. Several of the men remembered the clear rules 
about gender that they had learned from their father figures. Bhuti learned that it should be

... the man who have the say in everything happening around the house as the head of the house a man take decisions in everything and that I shall not be rule by a woman. (Bhuti)

I got to understand that a man is the head of the house and should therefore take care of his family and be the responsible one. (Dave)

You know, as a boy, I would say the positive aspect of being fathered was the fact that my grandfather believed that a boy should never be around women or gossip with women. The part that I liked the most was the fact that he would never allow us to wash dishes, saying it's women work. He would often say, 'Boys will always be boys, they must look after livestock and women must do the cooking'. (Simphiwe)

Inflexible rules built around gender and masculinity inside the home thus facilitated violence in the name of fatherhood when family members transgressed. Several participants remembered their fathers employing force to assert their authority:.

we were beaten a lot by my father when we have done something wrong or we did not hear his instructions. (Xola)

When I was a boy I was very scared of my father because of his violent behaviours when he was drunk. (Dave)

... it was a bad experience, my father used to hit us with shambock, he would line us up according to our age and would just hit, he did not care where he was hitting ... we were scared and my mother was scared too but she did nothing because my father was going to hit her too. (Peter)

Several participants rationalized this violence as necessary and meaningful, as in the best interests of children whose actions had overstepped the boundaries of acceptable behaviour as defined by their social fathers:

I would not say he was being verbally violent or physically violent towards us. Of course when we had done wrong he would shout at us and give us a hiding. I did not see that as being violent. (Xolile, our emphasis)

My father was never physically and verbally violent to me ... when I was young he disciplined me by beating me not violently. (Thabo)

Hayike, my grandfather used to beat us up when we wronged ... but not in the way that would make me think he hates me, but in the manner that made me understand that he is not killing you, he just want you to be in line ... No [my grandfather] was never violent. (Simphiwe) 
Here, violence is understood and legitimized as an expression of love and concern rather than abuse, resonating strongly with South African studies highlighting popular discourses constructing male violence towards female partners as expressions of love and caring (see, for example, Wood et al. 1996, Shefer et al. 2000, Shefer 2009). Thus in thinking back to their boyhoods, the narratives of our participants centralized the need for their fathers to stand alone, to provide for, and protect subordinate wives and children. Resonating with a range of studies describing patriarchal masculinities founded upon dominance, autonomy, and independence, many of our participants also understood physical violence as inherent, unavoidable, and necessary behaviours aimed at protecting the autonomy and authoritarianism of the patriarch (Connell 1995, Kimmel et al. 2005, Clowes 2006, Ratele 2008).

\section{Challenging normative constructions of fatherhood}

While we have foregrounded the traditional constructions of fatherhood and its enmeshment with control, power, and violence, there were also multiple moments when alternative discourses surfaced. These discourses challenged the narratives built around 'standing on your own two feet' and control and violence, offering glimpses of men embedded within communities engaged in a variety of non-hierarchical relationships with neighbours and friends as well as family. Suchmoments also challenged normative understandings that it was men's work/duty to lead and the role of women and children to follow. In particular, the data highlight a range of valuable and positive aspects of fathering (by biological and social fathers) as modelling nurturance and interdependence, forgiveness, humility, respect, consultative decision-making, and the antithesis of fear and violence. When asked whether he remembered ever being scared of his father, Lihle revealed that his father had emphasized that fear divided people and prevented them from asking for help:

My father was a very easy man to understand, so I never feel that anyone of us felt scared of him in my life... That was a thing that he taught amongst us telling us that if you fear one another, that means that it will difficult to ask for help from one another. That was the thing of fearing. (Lihle)

Abel drew attention to similar lessons from the two men who were significant masculine role models in his childhood:

To be a man I think first things first. You need to respect other people, because that is what my father told us ... What my uncle really told me is everybody makes mistakes and you need to be forgiving in order to live in peace with other people ... my father ... when he and my mother had huge arguments, he never spoke back, and that is the thing that I learned from him and that I apply in my life when I have arguments. (Abel)

Other men remembered how their father figures tried to resolve conflict through talking and more consultative forms of interaction:

my uncle was always a humble man, when there is a conflict he would try to resolve it by talking to the parties that are involved ... He always included me in taking part in the decisions that concerned our family. If there was a ritual that needed to be performed he 
would consult with me, even though he would do it even if I disapproved of it, but what made me happy was the fact that he informed about everything. (Xolile)

Abdul remembered that in his family his father set limits and imposed discipline by withholding privileges rather than resorting to violence:

... his limits weren't so, what I would call harsh and he gives you rope and when he sees you too far pulls the rope back, so that you now know that you have gone too far and he never used to use harsh words with us . . . the punishment . . . was you won't go to bioscope [cinema] with him or you won't get a ice-cream or whatever, that is how he punished us. (Abdul)

\section{Conclusions}

The data emerging out of this study suggest that we need a more nuanced understanding of South African fatherhood, one that takes into account the significance of the nurturing practices of social fathers - men who are neither biological fathers nor part of the nuclear family. The study suggests that the biological determinism of 'real' fatherhood needs to be challenged - not to 'let men off the hook' of parenting their biological children - but to accommodate the multiplicity and fluidity of family structures in South African society. It is in the interests of men themselves, as well as women and children, that we begin to acknowledge more flexible versions of masculinity, fatherhood, and family and to foreground local experiences that emphasize the fathering roles of all adult men. In addition, although not the focus of this study, there were hints (supporting the work of Langa 2010) that our participants admired their mother's or grandmother's ability to take on leadership roles within the family. Conceptualizing men as sole breadwinners, as independent and autonomous household heads, is an inaccurate representation of both the past and the present. Given both local and global social, economic, and political change, it is also an increasingly unsustainable aspiration for the future. Such gendered expectations are, furthermore, harmful to both men and women as well as their children with respect to the pressures it puts on men and the relationships between men and women in a society in which gender equity is a constitutional requirement.

Deconstructing the conflation of successful masculinity with breadwinning and authoritarianism in the home is an imperative in a society striving for economic and social justice. Challenging gender-based violence (including the violence that men perpetrate on each other) means challenging traditional notions of masculinity as a social location expressed through power over others; as a location founded on a denial of mutual interdependences and vulnerabilities; as a location from which violence is legitimized as both a framing and necessary practice for boys and men aspiring to successful masculinity. Thus the globally dominant trope of the patriarch and its embeddedness in the position of biological father needs to be challenged as part of wider struggles (for example, those against gender-based violence). This requires a reconceptualization of both masculinity and fathering so that understandings of violence, autonomy, and authoritarianism as constituting legitimate forms of fatherly love and protection are rendered unimaginable. 


\section{Acknowledgements}

This material is based upon work supported by the National Research Foundation (NRF). Any opinion, findings, and conclusions or recommendations expressed in this material are those of the authors, and therefore the NRF does not accept any liability in regard thereto. We would also like to thank the reviewers at the Journal of Gender Studies for their comments.

\section{Notes}

1. We would like to thank Tasneem Seboa, Stacy Mclean, Qiqa Mcilongo, A.J. Matthews, Olwethu Mabhanga, Sandisiwe Lutya, Nondumiso Kwinana, Sinako Flatela, and Xolani Dodi for giving us permission to draw on their transcripts.

2. In using these racial distinctions we acknowledge them as social constructs that have (and continue to have) a profound impact on material lives and experiences and the meanings attributed to them by South African citizens.

\section{Notes on contributors}

Lindsay Clowes holds a PhD in History and is currently the Chairperson of the Women's and Gender Studies Department at the University of the Western Cape. She is interested in South African women's history as well as change over time in identities built around gender, race, and sexuality.

Kopano Ratele is a Professor at the Institute of Social and Health Sciences at the University of South Africa (UNISA), Co-director of the Medical Research Council-UNISA Safety and Peace Promotion Research Unit, and Editor-in-chief of African Safety Promotion: A Journal of Injury and Violence Prevention.

Tamara Shefer is a Professor in Women's and Gender Studies and Psychology at the University of the Western Cape. Her research and publications are in the areas of heterosexuality; gendered, raced, and sexual identities and practices; masculinities; and critical and feminist psychology. 


\section{References}

Arnfred, S., 2001. Simone de Beauvoir in Africa: 'woman 1/4 the second sex?' Issues of African feminist thought. In: A. Johansson, ed. Svensk genusforskning i va“rlden. Globala perspektiv I svensk genusforskning och svensk genusforskning i ett globalt perspektiv. Go “teborg, Go " teborgs Universitet: Nationella Sekretariatet fo“ r genusforskning, 62-83.

Barnes, T., 1999. We women worked so hard: gender, urbanisation and social reproduction in colonial Harare, Zimbabwe, 1930-1956. Portsmouth: Heinemann.

Bozalek, V., 2004. Recognition, resources, responsibilities, using students' stories of family to renew the South African social work curriculum, Unpublished doctoral thesis, Utrecht University.

Bozalek, V., 2007. Analysing a text on the prevailing paradigm of 'family' in the 'psy' professions. In: T. Shefer, F. Boonzaier, and P. Kiguwa, eds. The gender of psychology. Cape Town: UCT Press, 151-164.

Bronte-Tinkew, J., et al., 2006. The influence of father-involvement on youth risk behaviors among adolescents: a comparison of native-born and immigrant families. Social Science Research, 35 (1), 181-209.

Brown, J. and Barker, G., 2004. Global diversity and trends in patterns of fatherhood. In: Supporting fathers: contributions from the international fatherhood summit 2003. Den Haag: Bernard van Leer Foundation, 16-43.

Burgess, B. and Russell, G., 2004. Fatherhood and public policy. In: Supporting fathers: contributions from the international fatherhood summit 2003. Den Haag: Bernard van Leer Foundation, 108-145.

Burke, T., 1996. Lifebuoy men, Lux women: commodification, consumption, and cleanliness in modern Zimbabwe. London: Leicester University Press.

Burman, E. and Parker, I., 1993. Discourse analytic research: repertoires and readings of texts in action. London: Routledge.

Busfield, J., 1996. Men, women and madness: understanding gender and mental disorder. New York: New York University Press.

Choi, J. and Jackson, A.P., 2011. Fathers' involvement and child behavior problems in poor African American single-mother families. Children and Youth Services Review, 33, 698-704.

Clowes, L., 2005. The families of men. In: R. Morrell and L. Ouzgane, eds. African masculinities. Houndmills, UK: Palgrave Macmillan, 89-108. 
Clowes, L., 2006. Men and children: changing constructions of fatherhood in Drum Magazine, 1951-1965. In: L. Richter and R. Morrell, eds. Baba: men and fatherhood in South Africa. Cape Town: HSRC Press, 108-117.

Clowes, L., Lazarus, S., and Ratele, K., 2010. Risk and protective factors to male interpersonal violence: the views of some male university students. African Safety Promotion Journal, 8 (1), 1-18.

Connell, R.W., 1995. Masculinities. Cambridge, UK: Polity Press.

Crehan, K., 1997. The fractured community - landscapes of power and gender in rural Zambia. Berkeley, CA: University of California Press.

Flouri, E. and Buchanan, A., 2003. The role of father involvement in children's later mental health. Journal of Adolescence, 26, 63-78.

Gibson, D. and Rosenkrantz Lindegaard, M., 2007. South African boys with plans for the future: why a focus on dominant discourses tells us only part of the story. In: T. Shefer, et al. eds. From Boys to men: social constructions of masculinity in contemporary society. Cape Town: UCT Press, 128-144.

Hearn, J., 2007. The problems boys and men create, the problems boys and men experience. In: T. Shefer, et al. eds. From boys to men: social constructions of masculinity in contemporary society. Cape Town: UCT Press, $13-32$.

Holborn, L. and Eddy, G., 2011. First steps to healing the South African family. Johannesburg: South African Institute of Race Relations.

Hosking, A., 2006. Men, work and parenting. In: L. Richter and R. Morrell, eds. Baba: men and fatherhood in South Africa. Cape Town: HSRC Press, 216-225.

Hunter, M., 2006. Fathers without amandla: Zulu-speaking men and fatherhood. In: L. Richter and R. Morrell, eds. Baba: men and fatherhood in South Africa. Cape Town: HSRC Press, 99-107.

Kimmel, M.S., Hearn, J., and Connell, R.W., eds, 2005. Handbook of studies on men and masculinities. London: Sage.

Langa, M., 2010. Adolescent boys talk about absent fathers. Journal of Psychology in Africa, 20 (4), 527-536.

Lewis, C. and Lamb, M.E., 2004. Fathers: the research perspective. Supporting fathers: contributions from the international fatherhood summit 2003. Den Haag: Bernard van Leer Foundation, 78-107. 
Lindsay, L.A., 2007. Working with gender: the emergence of the 'male breadwinner' in colonial Southwestern Nigeria. In: C. Cole, T. Manuh, and S. Miescher, eds. Africa after gender. Bloomington: Indiana University Press, 241-252.

Lupton, D. and Barclay, L., 1997. Constructing fatherhood: discourses and experiences. London: Sage.

Markowitz, S., 2001. Pelvic politics: sexual dimorphism and racial difference. Signs: Journal of Women in Culture and Society, 26 (2), 389-414.

McClintock, A., 1995. Imperial Leather: race, gender and sexuality in colonial conquest. Routledge: London.

Mfecane, S., 2008. Living with HIV as a man: implications for masculinity. Psychology in Society, 36, 45-59.

Mkhize, N., 2006. African traditions and the social, economic and moral dimensions of fatherhood. In: L. Richter and R. Morrell, eds. Baba: men and fatherhood in South Africa. Cape Town: HSRC Press, 183-198.

Moane, G., 1999. Gender and colonialism. Basingstoke: Macmillan.

Morrell, R., 2007. Do you want to be a father? School-going youth in Durban schools at the turn of the 21st century. In: T. Shefer, et al., eds. From boys to men: social constructions of masculinity in contemporary society. Cape Town: UCT Press, 75-93.

Morrell, R. and Richter, L., 2006. Introduction. In: L. Richter and R. Morrell, eds. Baba: men and fatherhood in South Africa. Cape Town: HSRC Press, 1-12.

Niehaus, I., 2005. Masculine domination in sexual violence: interpreting accounts of three cases of rape in the South African lowveld. In: G. Reid and L. Walker, eds. Men behaving differently: South African men since 1994. Cape Town: Double Storey, 65-88.

Oyewumi, O., 1997. The invention of woman: making an African sense. Minneapolis: University of Minnesota Press.

Parker, I., 1992. Discourse dynamics: critical analysis for social and individual psychology. London: Routledge.

Potter, J. and Wetherell, M., 1987. Discourse and social psychology: beyond attitudes and behaviour. London: Sage.

Ratele, K., 2008. Masculinity and male mortality in South Africa. African Safety Promotion: A Journal of Injury and Violence Prevention, 6 (2), 19-41.

Richter, L. and Morrell, R., eds, 2006. Baba: men and fatherhood in South Africa. Cape Town: HSRC Press. 
Seedat, M., van Niekerk, A., Jewkes, R., and Suffla, S., 2009. Violence and injuries in South Africa: prioritising an agenda for intervention. The Lancet, 374 (9694), 1011-1022.

Shefer, T., A qualitative study of UWC students' perceptions of the current context of (hetero)sexual practices on UWC campus. Unpublished report commissioned by the HIV/AIDS unit, University of the Western Cape.

Shefer, T., Strebel, A., and Foster, D., 2000. Discourses of power and violence in students' talk on heterosexual negotiation. South African Journal of Psychology, 30 (2), 28-36.

Shefer, T., et al., 2007. From boys to men: an overview. In: T. Shefer, et al. eds., From boys to men: social constructions of masculinity in contemporary society. Cape Town: UCT Press, 1-12.

Sideris, T., 2005. 'You have to change and you don't know how!' Contesting what it means to be a man in a rural area of South Africa. In: G. Reid and L. Walker, eds. Men behaving differently: South African men since 1994. Cape Town: Double Storey, 111-138.

Silberschmidt, M., 2004. Masculinities, sexuality and socio-economic change in rural and urban East Africa. In: S. Arnfred, ed. Re-thinking sexualities in Africa. Sweden: NordiskaAfrikainstitutet, 233-249.

Sinha, M., 1997. Colonial masculinity: the 'manly Englishman' and the 'effeminate' in the late nineteenth century. New Delhi: Kali for Women Press.

Statistics South Africa, 2000. Women and men in South Africa: five years on. Pretoria: Statistics South Africa.

Statistics South Africa, 2011. Quarterly labour force survey quarter 1. Pretoria: Statistics South Africa.

Swartz, S. and Bhana, A., 2010. Teenage Tata: voices of young fathers in South Africa. Cape Town: HSRC Press.

van Dijk, T.A., 1993. Principles of critical discourse analysis. Discourse and Society, 4 (2), 249-283.

Walker, L., 2005. Negotiating the boundaries of masculinity in post-apartheid South Africa. In: G. Reid and L. Walker, eds. Men behaving differently: South African men since 1994. Cape Town: Double Storey, 161-182.

Wilson, F., 2006. On being a father and poor in South Africa today. In: L. Richter and R. Morrell, eds. Baba: men and fatherhood in South Africa. Cape Town: HSRC Press, 26-38.

Wood, K., Maforah, F., and Jewkes, R., 1996. Sex, violence and constructions of love among Xhosa adolescents: putting violence on the sexuality education agenda. Tygerberg, Cape Town: Medical Research Council. 